\title{
THE EFFECT OF TEACHING STYLES AND COORDINATION TO THE LEARNING RESULT OF TABLE TENNIS SKILLS
}

\author{
E. Fitri Amalia*, James Tangkudung**, Firmansyah Dlis*** \\ State University of jakarta \\ fitriamalia120@gmail.com \\ jamestangkudung@unj.ac.id \\ Firmansyahdlis@unj.ac.id
}

\begin{abstract}
The purpose of this research is to know the difference of influence of teaching style and coordination to the learning result of table tennis skill. The research was conducted on Physical education health and recreation University of education indonesia students. The research method used experiment with $2 \times 3$ factorial design, using 60 samples. Based on the results of research and discussion can be concluded that are as follows: 1) There is a difference in the influence of command teaching style with reciprocal teaching style to the learning outcomes of table tennis skills to students as a whole. 2) There is a difference in the influence of the command teaching style with the inclusive teaching style on the learning outcomes of table tennis skills to the students as a whole. 3) There is a difference in the influence of reciprocal teaching style with the teaching style of inclusion to the learning outcomes of table tennis skills to the students as a whole. 4) There is an interaction between the teaching style and the coordination of the learning outcomes of table tennis skills to the students. 5) There is a difference in the influence of command teaching style with the reciprocal teaching style on the learning outcomes of table tennis skills in groups of students who have high coordination. 6) There is a difference in the influence of the command teaching style with the inclusive teaching style on the learning outcomes of table tennis skills in the group of highly coordinated students. 7) There is a difference in the influence of reciprocal teaching styles with inclusive teaching styles on the learning outcomes of table tennis skills in groups of highly coordinated students. 8) There is a difference in the influence of the command teaching style with the reciprocal teaching style on the learning outcomes of table tennis skills in groups of students with low coordination. 9) There is a difference in the influence of the command teaching style with the teaching style of inclusion to the learning outcomes of table tennis skills in the group of students who have low coordination. 10) There is a difference in the influence of reciprocal teaching styles with inclusive teaching styles on the learning outcomes of table tennis skills in groups of students with low coordination.
\end{abstract}

Keywords: Teaching Style, Command, Reciprocal, Inclusion, Coordination

To achieve the optimum table tennis performance requires a careful, continuous, systematic, tiered and continuous learning and training process with appropriate teaching styles. Currently, several styles of teaching are expressed by educational experts and sport coaches, but until now there has been no particular style of training and teaching styles designed for students who can be used as reference for lecturers of physical education and trainers. Therefore, the problem that needs to get attention and sought solving is how the teaching style is suitable for students in learning table tennis game based on concept and learning theories, and can explain how the learning process to improve table tennis skills. For that need to be tested some style of teaching, among which often become discussion is teaching style oriented to lecturers and there is also oriented to student.

Some of the teaching styles are often performed among others who teach by using the style of command teaching, reciprocal style, and style of inclusion. The teaching style refers to the learning that is often done in physical education education. Mosston and Ashwort present eleven teaching 
styles that are often performed, as follows: (1). Command Style (command style), (2). The practice style; (3). Repsiprokal style (Resiprocal style); (4). The self-ceck style; (5). The inclusion style; (6) Guided discovery style; (7). Confergent style style; (8). The divergent production style, (9). Individual program style (the individual program-linear design style). (10). The learner initiated style, and (11). Self-teaching style. (Mosston, 2008)

The teaching style is the lecturer's appearance in implementing the learning in accordance with its ability to encourage students in the effort to exploit the skills in table tennis game. This teaching style can affect the learning atmosphere which can ultimately affect student learning outcomes on campus. Some of the popular teaching styles and author's observations include command styles, reciprocal styles, and inclusion styles. This study was limited to testing the influence of command, reciprocal, and inclusion teaching styles as independent variables, as well as coordination as a moderator variable, to the learning outcomes of table tennis skills in the male students as the dependent variable.

The research was conducted to the students who participated in the table tennis at the Physical Education Study Program of Health and Recreation of 5 in Bandung West Java in the academic year 2017-2018. In order to formulate the problem can be clearly understood, it should be mentioned the operational definition of the variables and terms used in this study as follows:

1) Learning outcomes, defined as the level of performance or level of ability and mastery of students towards learning objectives within a certain time. 2) Table tennis skill, is the ability of a table tennis player to perform or present a typical movement and is used in table tennis. Table tennis skills were measured through table tennis skills test compiled and standardized in this study. 3) Teaching style, is a process of organizing, organizing the environment around students, so it can grow and encourage students to do the process of providing guidance or assistance to students in the learning process. 4) Command style, is a teaching style that is done with direct response from lecturer to student, aims to obtain a careful appearance by following instructions, all decisions made by lecturers, to produce high level of activity, discipline behavior and obey the established procedures. 5) Reciprocal style, is a way of delivering learning aimed at improving students' movement ability by diverting some decisions regarding learning activities from lecturers to students. The decisions include the execution of the task of movement and the delivery of feedback to peers in a pair and mutual provide feedback, based on the criteria provided by the teacher. 6) The style of inclusion, is the teaching style which in presenting the overall learning material presented, then Students are given the freedom to choose and determine on the difficulty level where the student starts to study, how many times the students have to repeat the movement in studying a movement technique in each meeting. and offers a challenge to check the results of his work. 7) Coordination, is the ability to perform movements with various levels of difficulty quickly and efficiently and with full accuracy. 8) Student; is a student who follows the table tennis course in semester V program of Physical Education Education and Recreation of Physical education health and recreation University of education indonesia students in the academic year 20172018.

Teaching style is a way that is done to achieve learning objectives, create an atmosphere of learning environment and choose the learning activities, then the style of teaching is a pattern of approaches in the form of guidelines or guidelines and framework activities so that students can learn and achieve learning outcomes. Further explained by Pestaloozi (Suryosubroto, 2010) that in the learning process should be treated like a human, must be educated according to his needs, and learn something useful for him. The learning process by using appropriate teaching strategies is very important in the effort of effectiveness and efficiency in the process of organizing education. This is why lecturers are more experienced because of the teaching they have been doing for years and they find that what has been done for years is in line with current research. The style of command 
instruction is a teaching style with a direct response to the stimulus (the teacher gives an example and the student does it), aims to obtain a careful appearance by following the instructions of which are; (1) All decisions are made by the teacher (2) Following the instructions and carrying out the tasks are the main activities of the students (3) Generating high activity levels (4) Can make students feel involved and motivated (5) Develop disciplinary behavior, as must obey the procedure which has been set.

Basically everyone has different Coordination between each other. According Kirkendall et al (Kirkendall, 2010). Coordination is the work of a harmonious muscle group during motor performance and as an indication of the skill. Furthermore, according to Gallahue and Ozmun states that eye and hand coordination refers to the ability to track and make decisions about moving objects. (Gallahue and Jhon C. Ozmun) Later in support (Anita J. Harrow, James Tangkudung, 2012) suggests that, coordination is the ability to perform movements with various levels of difficulty quickly and efficiently and full of precision. Although innate and environmental factors are equally influential, but innate factors are considered the major forces affecting Coordination. Coordination aspect of a person is an integral part of the physical fitness component. Each individual has different levels of coordination and varies according to his or her potential for everyone. Gallahue and Ozmun stated that the coordination movement requires the integration of sensory and motor systems into the same and harmonious patterns. (Gallahue and Ozmun,) Zatgorsky in Bompa () proposes the criteria for fulfilling the coordinating requirements of which are; 1) Degree of difficulty; an individual skill or appearance that is easy or difficult oriented. 2) accuracy of appearance; a movement may be performed with high precision during a match. 3) Duration of acquisition; The complexity of a skill also relates to the time it takes to get it. Individuals who have good coordination tend to acquire a skill faster than those with less coordination. Based on the descriptions and opinions of the experts can be argued that the core of coordination is the cooperation of the nervous and muscle structure into an integrated movement in performing a motion skill.

\section{METHOD}

This research was conducted to students of physic education and health education students of Physical education health and recreation University of education indonesia students in Bandung West Java province. The study is planned to be conducted for 6 weeks with 3 (three) meetings per week, ie; Monday, Wednesday and Friday. Starting from 5 February to 16 March 2018, including the implementation of the initial and final tests. This study consisted of dependent variable that is learning result of table tennis skill, treatment variable that is teaching style consisting of command teaching style, reciprocal and inclusion. using attribute variables ie students who have high and low coordination. This research design using factorial design 2 × 3 (Akbar, 2013).

Design of Experimental Design of Factorial $2 \times 3$

\begin{tabular}{|l|l|l|l|}
\hline \multicolumn{3}{|c|}{ Teaching Style } & \multirow{2}{*}{ Total } \\
\cline { 1 - 3 } Command (A1) & Resiprocal (A2) & Inclusion (A3) & \\
\hline AIBI & A2B1 & A3B1 & B1 \\
\hline A1B2 & A2B2 & A3B2 & B2 \\
\hline A1 & A2 & A3 & \\
\hline
\end{tabular}

This research was conducted on the students of Physical Education and Health Education of Physical education health and recreation University of education indonesia students in Bandung West Java for 6 (six) weeks, with a meeting frequency of 3 (three) times a week. There are three types of treatment that will be done in this research that is, learning with Command style, reciprocal and inclusion. 


\section{Draft Treatment}

\begin{tabular}{|l|l|l|l|}
\hline \multirow{2}{*}{ Meeting } & \multicolumn{3}{|c|}{ Treatment } \\
\cline { 2 - 5 } 1 & \multicolumn{1}{|c|}{ Command Style } & \multicolumn{1}{|c|}{ Reciprocal Style } & \multicolumn{1}{c|}{ Style Inclusion } \\
\hline $2-17$ & $\begin{array}{l}\text { Explanation of learning } \\
\text { Command style }\end{array}$ & $\begin{array}{l}\text { Explanation of learning } \\
\text { reciprocal style }\end{array}$ & $\begin{array}{l}\text { Explanation of learning } \\
\text { Inclusion style }\end{array}$ \\
\hline 18 & Style with Command & $\begin{array}{l}\text { Learn with Reciprocal } \\
\text { Style }\end{array}$ & Learn with Style Inclusion \\
\hline
\end{tabular}

The study was conducted by forming six parallel groups, each group performing activities as in table 4 (treatment design) above. The execution time to learn Command style, reciprocal and Inclusion, each for 90 minutes from 14.00 - 15.30.

The population of this study are all students of semester V students who are students of physical health education and recreation studies of Physical education health and recreation University of education indonesia students in the academic year 2017/2018 amounted to 112 students, sample groups that have high and low coordination.

Grouping of Research Samples

\begin{tabular}{|l|c|c|c|}
\hline \multicolumn{1}{|c|}{ Style (A) } & $\begin{array}{c}\text { Command } \\
\text { Coordination (B) }\end{array}$ & $\begin{array}{c}\text { Reciprocal } \\
\text { (A2) }\end{array}$ & $\begin{array}{c}\text { Inclusion } \\
\text { (A3) }\end{array}$ \\
\hline High (B1) & 10 & 10 & 10 \\
\hline Low (B2) & 10 & 10 & 10 \\
\hline Total & 20 & 20 & 20 \\
\hline
\end{tabular}

For the determination of the form of style of teaching followed followed by using the lottery technique. Implementation of lottery done twice; First in the high coordination group, the draw was taken to follow the style of Command, reciprocal, and inclusion. Both in the low coordination group were drawn to determine the sample groups following Command, reciprocal and inclusion.

In the process of data collection always requires an instrument to obtain data. Testee tries first from the service movement, push, drive, in sequence. Both forehand and backhand. Coordination can be conceptually defined as follows; Coordination is defined as a harmonious relationship of the interplay of influence between groups of muscle groups during work performed by different levels of skill. To conduct a table tennis coordination test first tested to determine the validity of internal and reliability. So it can be standardized in this research. The data obtained in this study, processed and analyzed by using variance analysis technique (ANAVA), and continued by further testing Tukey test. Because this research is a $2 \times 3$ factorial design design. Data analysis using ANAVA with belief level $\alpha$ $=0,05$. followed by the equation requirement test that is Normality Test using Lilifors Test. And for homogeneity test of variance using Barlet Test with trust level $=0.05$.

\section{RESULT AND DISCUSSION}

The data of learning result of table tennis skill in this research is result of treatment by applying three types of teaching style (reciprocal, training, and inclusion) combined with student coordination skill (high and low). Description of data of learning result of table tennis skill is described as follows

\section{Description of Overall Teaching Style Data}

\begin{tabular}{|l|l|l|}
\hline Descriptive Statistics & & \\
\hline Dependent Variable: Results of Learning Table Tennis Skills & & \\
\hline
\end{tabular}




\begin{tabular}{|l|l|l|l|l|l|l|}
\hline Teaching Style & Koordinasi & High Score & Low Score & Mean & Std. Deviation & N \\
\hline Command & High & 181,73 & 24,17 & 28.00 & .35 & 0 \\
\cline { 2 - 7 } & Low & 118,45 & 05,35 & 11.90 & .16 & 0 \\
\cline { 2 - 7 } & Total & 114,79 & 25,11 & 19.95 & 1.02 & 0 \\
\hline \multirow{5}{*}{ Reciprocal } & High & 147,26 & 38,54 & 42.90 & .10 & 0 \\
\cline { 2 - 7 } & Low & 115,76 & 06,04 & 10.90 & .79 & 0 \\
\cline { 2 - 7 } & Total & 118,67 & 35,13 & 26.90 & 7.58 & 0 \\
\hline Inclusion & High & 154,02 & 50,78 & 52.30 & .41 & 0 \\
\cline { 2 - 7 } & Low & 115,28 & 18,98 & 15.30 & .14 & 0 \\
\cline { 2 - 7 } & Total & 124,73 & 42,87 & 33.80 & 9.38 & 0 \\
\hline Total & High & 136,88 & 45,25 & 41.07 & 1.22 & 0 \\
\hline \multirow{5}{*}{} & Low & 110,00 & 15,40 & 12.70 & .23 & 0 \\
\cline { 2 - 7 } & Total & & & 26,88 & 0,47 & 0 \\
\hline
\end{tabular}

Source: Primary Data Processing Result (2018)

\section{Preparation Test Analysis}

\section{Test Data Normality}

Normality test data is done to determine whether or not normal data obtained in the research process. Normality testing was performed on each treatment data group with $\alpha=0,05$ which was done by using Liliefors test with SPSS program as follows.

\begin{tabular}{|l|c|c|c|c|}
\hline \multirow{2}{*}{ Group } & \multicolumn{2}{|c|}{ Kolmogorov-Smirnov $^{\mathbf{a}}$} & \multirow{2}{*}{ Conclusion $^{*}$} \\
\cline { 2 - 4 } & Statistic & Df & Sig. & \\
\hline High Command & 0.154 & 10 & $0.200^{*}$ & Normal \\
\hline High Reciprocal & 0.207 & 10 & $0.200^{*}$ & Normal \\
\hline High Inclusion & 0.214 & 10 & $0.200^{*}$ & Normal \\
\hline Low Command & 0.218 & 10 & 0.196 & Normal \\
\hline Low Reciprocal & 0.124 & 10 & $0.200^{*}$ & Normal \\
\hline Low Inclusion & 0.200 & 10 & $0.200^{*}$ & Normal \\
\hline
\end{tabular}

Source: Results of data processing with SPSS (2018)

Based on Table 4:24 it is known that the p-value (sig) result of the analysis with SPSS in each treatment group as a whole obtained sig value> 0.05 as seen from the column sig KolmogorovSmirnova. Thus, H0 is accepted and H1 is rejected. That is, all data obtained in the treatment group has a normal distribution.

\section{Data Homogeneity Test}

Data homogeneity test is done on the whole data to know homogenous or not data obtained from research result. The testing process was conducted through SPSS assisted Barlett test as follows.

\section{Test of Homogeneity of Variances}

\begin{tabular}{|l|l|l|l|}
\hline Levene Statistic & df1 & df2 & Sig. \\
\hline 1.213 & 5 & 54 & 0.316 \\
\hline
\end{tabular}

Source: Results of data processing with SPSS (2018)

Based on Table 4:25 above, note that the value of $p$-vaue (sig) $=0.316$ or $0.316>0.05$. Then $\mathrm{H} 0$ is accepted and $\mathrm{H} 1$ is rejected. Thus, the data of table tennis skills acquired comes from the same group or population.

\section{Hypothesis testing}


Hypothesis testing is done by Analyze Variance (ANAVA) technique one lane and two lane then continued by doing Tuckey test.

One-way ANAVA analysis was conducted with the aim of knowing the differences of influence between groups without looking at attribute variables, ie differences in influence between reciprocal groups, inclusion and command. The following test results $\mathrm{F}$ (anava) and further tests using tukey test are presented in Table 4:26.

\section{Results of One Path Variance Analysis}

\begin{tabular}{|l|l|l|l|l|l|}
\hline & Sum of Squares & Df & Mean Square & F & Sig. \\
\hline Between Groups & 918.233 & 2 & 959.117 & 3.570 & 0.035 \\
\hline Within Groups & 5313.950 & 7 & 268.666 & & \\
\hline Total & 7232.183 & 9 & & & \\
\hline
\end{tabular}

Source: Test results with SPSS (2018)

Based on result of $F$ test analysis difference between influence, obtained value of $F(d k 2,57)$ equal to 3,57 and significant at $p$-value 0,035 . Because $p$-value value 0,035 is below $\alpha=0,05(0,035$ $<0,05)$ it means there is significant difference of influence between reciprocal group, inclusion and command to learning result of table tennis skill.

Results Analysis of One Path Variance

\begin{tabular}{|l|l|l|l|l|}
\hline \multirow{2}{*}{ (I) Style } & $(J)$ Style & Mean Difference (I-J) & Std. Error & Sig. \\
\hline \multirow{2}{*}{ Comand } & Reciprocal & 6.95 & & \\
\cline { 2 - 5 } & Inclusion & 13.85 & 5.183 & 0.379 \\
\hline \multirow{2}{*}{ Reciprocal } & Comand & 6.95 & 5.183 & 0.026 \\
\cline { 2 - 5 } & Inclusion & 6.90 & 5.183 & 0.379 \\
\hline \multirow{2}{*}{ Inclusion } & Comand & 3.850 & 5.183 & 0.384 \\
\cline { 2 - 5 } & Reciprocal & 6.90 & 5.183 & 0.026 \\
\hline
\end{tabular}

Source: Test results with SPSS (2018)

Furthermore, to see the effect of intergroup can be further seen from post-anava test by using Tukey HSD technique, following hypothesis testing formulated will be discussed further.

\section{Differences in learning outcomes of Table A1 and A2 table tennis skills.}

Based on the results of the analysis in Table 4:27 on differences in learning outcomes of table tennis skills of students group taught by using the teaching style of reciprocal and style of command command obtained value $\mathrm{Sig}=0.379$, because the value of significance exceeds alpha $0.05(0.379>0.05)$, thus $\mathrm{H} 0$ is accepted and $\mathrm{H} 1$ is rejected. It can be concluded that there is no significant difference between the teaching style of reciprocal (A1) and command (A2) to the overall learning outcomes of table tennis skills. (First Research Hypothesis Rejected)

\section{Differences in learning outcomes of Table A1 and A3 table tennis skills}

Based on the results of the analysis in Table 4:27 on differences in learning outcomes of table tennis skills of students group taught by using reciprocal teaching style and inclusion teaching style obtained Sig value $=0.384$, because the value of significance exceeds the alpha value (0.384> 0.05), thus $\mathrm{H} 0$ received and $\mathrm{H} 1$ is rejected, meaning there is no significant difference of influence between reciprocal learning model (A1) and inclusion learning model (A3) to the overall learning result of table tennis skill, hence the Second Research Hypothesis Rejected.

\section{Differences in learning outcomes of Table A2 and A3 table tennis skills}

Based on the results of the analysis in Table 4:27 on differences in learning outcomes of table 
tennis skills of students group taught by using the command teaching style (A2) and inclusion teaching style (A3) obtained significance value $=0.026$, because the significance value less than $0.05(0.026<005)$, thus $\mathrm{H} 0$ is rejected, meaning that there is a significant influence difference between the command instruction model (A2) and the inclusive learning model on the overall learning outcome of table tennis skills. Thus the third research hypothesis is accepted.

\section{Interaction of teaching styles and coordination of learning outcomes of table tennis skills}

Based on the calculation result of test of between-subject effect at Table 4:27 dibolkan significance value of 0.000 , because the value of significance less than alpha $0,05(0,00<0,05)$, meaning $\mathrm{H} 0$ rejected, in other words there is interaction influence of teaching style and coordination of the learning outcomes of table tennis skills. Thus the fourth Research Hypothesis is accepted.

To strengthen the results of the analysis and interpretation of interaction results will be poured with interaction graphs between groups in both reciprocal, command and inkulsi groups by looking at high coordination and low coordination variables,

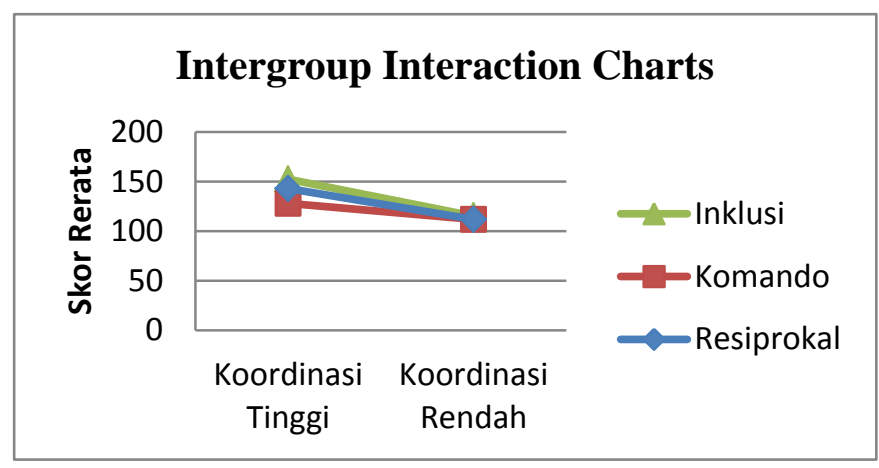

Figure 4.12 Graph The Influence of Interaction between Teaching Style and Coordination of Learning Outcomes Table tennis skills

Based on Figure 4. 12 of the third line of treatment groups met at one end of the line, meaning that all teaching styles and coordination levels have an influence between variables. There is a significant interaction between the teaching style and the co-ordination of the learning outcomes of table tennis skills in Faculty of Education Sport and Health Physical Education Health \& Recreation university education indonesia Bandung students.

5. Differences in Learning Outcomes Table Tennis Skills Between Following Teaching Style Command with Reciprocal Teaching Style On High Coordinate Students.

Based on result of difference analysis between group "multiple comparisons" with tukey technique in table 4:28 to answer hypothesis no 5 that difference between command group (A2B1) and reciprocal (A1B1) with high coordination obtained by Mean Difference value equal to -14.90 and significance of 0,00 . Since the significance value is less than $\alpha=0.05(0.00<0.05)$, it means that $\mathrm{H} 0$ is rejected, in other words there is a difference in learning outcomes between table tennis skills that follow the command teaching style with reciprocal teaching style in students who have high coordination . Thus the Fifth Research Hypothesis is accepted.

6. Differences in Learning Outcomes Table Tennis Skills Between Following Teaching Style Command with Teaching Style of Student Inkulsi Who Have High Coordination.

Based on result of difference analysis between group "multiple comparisons" with tukey technique in table 4:28 to answer hypothesis no 6 that difference between command group (A2B1) and inclusion (A3B1) with high coordination obtained Mean Difference value equal to $-24,30$ and significance equal to 0,00 . Because the significance value is less than $\alpha=0.05(0.00<0.05)$, it 
means that $\mathrm{H} 0$ is rejected, in other words there is a difference in learning outcomes between table tennis skills that follow the style of command teaching with inclusive teaching style in students who have high coordination. Thus the Sixth Research Hypothesis is accepted.

7. Differences in Learning Outcomes Table Tennis Skills Between Following Style Teaching Reciprocal with Teaching Style of Inkulsi On Student Who Has High Coordination.

Based on result of difference analysis between group "multiple comparisons" with tukey technique in table 4:28 to answer hypothesis no 7 that difference between group of reciprocal (A1B1) and inclusion (A3B1) with high coordination obtained Mean Difference value equal to 9,40 and significance equal to 0,02 . Since the significance value is less than $\alpha=0.05(0.02$ $<0.05$ ), it means that $\mathrm{H} 0$ is rejected, in other words there is a difference in learning outcomes of table tennis skills among those following the reciprocal teaching style with inclusive teaching style in students who have high coordination. Thus the seventh Research Hypothesis is accepted.

8. Differences in Learning Outcomes Table Tennis Skills Between Who Followed Teaching Style Command with Reciprocal Teaching Style in Low-Coordinated Students.

Based on result of difference analysis between group "multiple comparisons" with tukey technique in table 4:28 to answer hypothesis no 8 that difference between command group (A2B2) and reciprocal (A1B2) with low coordination obtained value Mean Difference equal to 1.00 and significance equal to 1.00 . Because the value of significance is greater than $\alpha=0.05(1.00>0.05)$, it means that $\mathrm{H} 0$ is accepted, in other words there is no difference in learning outcomes of table tennis skills between follow the command teaching style with reciprocal teaching style in students who have low coordination. Thus the eighth Research Hypothesis is rejected.

Judging from the mean difference / difference of the average between groups obtained value of 1.00 , meaning the command group $(M=111.90)$ and reciprocal $(M=110.90)$ have the same average value, in other words in students who have the low coordination of commando groups and reciprocal groups had a similar effect on the learning outcomes of table tennis skills.

9. Differences Learning Outcomes Table Tennis Skills Between Following Style Teaching Command with Teaching Style of Inkulsi on Students with Low Coordination.

Based on result of difference analysis between group "multiple comparisons" with tukey technique in table 4:28 to answer hypothesis no 9 that difference between command group (A2B2) and inclusion (A3B2) with low coordination obtained by Mean Difference value equal to -3.40 and significance equal to 0,82 . Because the value of significance is greater than $\alpha=0.05(0.082>$ 0.05), it means that $\mathrm{H} 0$ is accepted, in other words there is no difference in learning outcomes of table tennis skills between those following the command teaching style with the teaching style of inclusion in the students who have low coordination. Thus the ninth Research Hypothesis is rejected.

10.Differences Learning Outcomes Table Tennis Skills Between Following Style Teaching Reciprocal with Teaching Style of Inclusion in Students with Low Coordination.

Based on result of difference analysis between group "multiple comparisons" with tukey technique in table 4:28 to answer hypothesis no 10 that difference between group of reciprocal (A1B2) and inclusion (A3B2) with low coordination obtained by Mean Difference value equal to 4.40 and significance equal to 0,061 . Because the value of significance is greater than $\alpha=0.05$ (0.061>0.05), it means that $\mathrm{H} 0$ is accepted, in other words there is no difference in learning outcomes of table tennis skills among those following the reciprocal teaching style with inclusive teaching styles in students with low coordination . Thus the tenth Research Hypothesis is rejected.

\section{CONCLUSION}

Based on the results of research and discussion that has been put forward there are several 
things that can be concluded that is as follows:

1. There is a difference in the influence of command teaching style with the reciprocal teaching style to the learning outcomes of table tennis skills to the students as a whole.

2. There is a difference in the influence of the command teaching style with the teaching style of inclusion to the learning outcomes of table tennis skills to the students as a whole.

3. There is a difference in the influence of reciprocal teaching styles with inclusive teaching styles to the learning outcomes of table tennis skills to students as a whole.

4. There is an interaction between the teaching style and the coordination of the learning outcomes of table tennis skills on the students.

5. There is a difference in the influence of the command teaching style with the reciprocal teaching style on the learning outcomes of table tennis skills in the group of highly coordinated students.

6. There is a difference in the influence of command teaching styles with inclusive teaching styles to the learning outcomes of table tennis skills in groups of highly coordinated students.

7. There is a difference in the influence of reciprocal teaching styles with inclusive teaching styles on the learning outcomes of table tennis skills in groups of highly coordinated students.

8. There is a difference in the influence of the command teaching style with the reciprocal teaching style on the learning outcomes of table tennis skills in the group of students who have low coordination.

9. There is a difference in the influence of the command teaching style with the inclusive teaching style on the learning outcomes of table tennis skills in groups of students with low coordination.

10.There is a difference in the influence of reciprocal teaching styles with inclusive teaching styles on the learning outcomes of table tennis skills in groups of students with low coordination.

\section{REFERENCE}

Bompa, O. Tudor. (2009). Theory dan Methodology of Trainning, Dubuque: Kendall/hunt Publishing Company.

Borg, Walter R. \& Meredith D. Gall. (1983). Education Research: an Introduction, New York, Longman, Inc.

Bowers, Richard W. dan Edward L. Fox . (1992). Spoprt Physiology, Dubuque Lowa: Wm. C Browns.

Brian J. Sharkey. (2003). Fitness and Health. Jakarta: PT. Rajagrafindo Persada.

B. Suryosubroto. (2009). Teaching and Learning Process in Schools, Multiple Support Methods, and some Special Service Components. Jakarta: PT. Rineka Cipta.

Byra, M., \& Jenkins, J. (2000). Matching Instructional Tasks to Learner Ability: The Inclusion Style of Teaching. Journal of Physical Education, Recreation \& Dance, 71(3), 26-30. https://doi.org/10.1080/07303084.2000.10605108

Cheryl A Coker. (2004). Motor Learning and Control for Practitioners. New York: McGraw-Hill Companies.

C.A. Hardy, dkk. (2003). Learning and Teaching in Physical Education. Taylor \& Prancis e-Library.

Deni Kurniawan. (2013). Thematic Integrated Learning, Bandung Alfabeta Publisher 2014. Dimyati, Mudjiono. Learning and Learning (Jakaarta, PT Rineka Cipta.

Don R. Kirkendall, Joseph J. Gruber, dan Robert E. Johnson. (2010). Measurement and Evaluation for Physical Educator. Dubuque Iowa: Wim C.Brown Company Publisher.

Edward Pajak. (2006). Honoring Diverse Teaching Style. Assosiation For Suvervision and Curriculum Development.

Elizabeth B. Hurlock. (2007). Developmental Psychology, A Life Range Approach, translation of Istimi widayanti and Soedjarwo, Jakarta: Erland.

Fank M. Verducci. (1980). Measurement Concepts in Physical Education, St.Louis Missouri: Mosby Company.

Harsuki. (2012). Introduction to Sports Management, Jakarta: PT. Rahagrafindo Persada 
Hasbunalloh. (2016). The Influence of Teaching Style and Motivation on the result of learning skill of forehand field tennis service, Experimental Study on Student FIK UNM Makassar, Jakarta: Graduate Program, Jakarta State University.

Harvey F. Shiffer, et al. (2012). Teaching Strategy, Jakarta, PT. Index.

Indramawan Putut. (2016). Contribute agility, hand eye coordination, speed, and arm power to precision forehand drive athletes Union Table tennis TT 27 Yogyakarta. Faculty of Sport Science, Yogyakarta State University.

Indra Safari. (2016). Effect of Exercise Method and Hand Eye Coordination on Accuracy Forehand Topspin Punch Table Tennis, Sports Education Graduate School, University of Education Indonesia, Bandung.

I Safari*, A Suherman, and M. A. U. (2017). The Effect of Exercise Method and Hand-Eye Coordination Towards the Accuracy of Forehand Topspin in Table Tennis. IOP Conf. Series: Materials Science and Engineering, 180(1), 3-10. https://doi.org/doi:10.1088/1757-899X/ $180 / 1 / 012207$

Ismaryati. (2008). Tests and Measurements of Sports. Solo: UNS Press, Prints II.

James Popham et al. (2008). Technique Teaching Systematically. Jakarta: Rineka Cipta.

James Tangkudung, and Wahyuningtyas P. (2012). Sports Coaching, Sports Performance Coaching, Second Edition. Jakarta: Smart Jaya Publisher.

James Tangkudung. (2015). Kinds of Research Methodology, Description and Examples. Jakarta: Publisher Lens Media Library.

Jonath Krempel in Syafruddin. (2011). Science Coaching Sports Theory and Its Application in Sport Coaching. Padang: UNP Press Padang.

Kate Morss and Rowena Murray. (2005). Taching at University. India: SAGE Publication India Ltd.

Ministry of Youth and Sports of the Republic of Indonesia. (2005). Law of the Republic of Indonesia no. 3 About the National Sport System. Jakarta: Ministry of Youth and Sports.

Khomsim. (2008). Sports Skills Learning. Ministry of Youth and Sport of the Republic of Indonesia.

Kolovelonis, A., \& Goudas, M. (2012). Students' recording accuracy in the reciprocal and the selfcheck teaching styles in physical education. Educational Research and Evaluation, 18(8), 733-747. https://doi.org/10.1080/13803611.2012.724938

Larry Hodges. (1993). Table Tennis, Step to Success. Human Kinetic Publisher.

Larry Hodges. (2007). Table Tennis Beginner Level, Step to Success. PT. Raja Grafindo Persada, Jakarta, Translator, Deri D.Nasution.

Lumintuarso Ria. (2013). Sports Coaching Theory, (Sports National Accreditation Institute) Ministry of Youth and Sports. Jakarta Indonesia.

Magill, A.Richard. (2011). Motor Learning, Concept \& Application, Dubuque: WM. C. Brown Publisher.

Magill, A. Richard. and Andersen, Motor Learning and Controll, Conceps And Aplication, McGraw Hill Company, New York, Tenth Edition, 2014.

Mamun Amung., Yudha M. Saputra. (2000). Motivation and Learning Motion. Jakarta: P \& K Department Directorate General of Primary and Secondary Education.

Mappaompo Adam. (2016). The Influence of Teaching Style and Motivation of Learning To the learning result of dribbling on football game.Dissertation, Jakarta: Graduate, Jakarta State University.

Maruf Akbar. (2013). Material Statistics II, Anova, Anacova, and Manova, Supporting Teaching Materials. Graduate Program State University of Jakarta.

Muhammaad Syaiful Sumantri. (2015). Learning Strategy. Jakarta PT Raja Grafindo Persada.Muska

Mosston ans Sara Asworth. (2008). Teaching Physical Education, (Online Edition), New York: MacMillan College Publising Company Inc.

Nathaniel L. Gage, A Conseption of Teaching, Springer Science, Stanford University School of Education Stanford, CA USA, 2009.

Ngalimun. (2013). Learning Strategies and Models. Sleman Yogyakarta, Aswaja Pressindo.

Oemar Hamalik. (2009). Learning process. Jakarta PT Bumi Aksara.

Open Stax. (2016). Anatomy and Fisiology, Rice University, 60100 Main Street MS-375, HoustonTexas. 
Purwanto. (2014). Evaluation of Learning Outcomes. Yogyakarta: Pustaka Pelajar.

Rahmat Pamuji. (2007). Effectiveness Between Aerobic Gymnastics Low Impact with Cardio Circuit Training to decrease body fat percentage, Jakarta.

Rex Jhonson dan David Swindley. (2009). Creating Confidence: The Secrets of Self Esteem, Melbourne: Element.

Rahayu Ega Trisna. (2013). Physical Education Learning Strategy. Bandung: Alfabeta.

Richard A. Schmidt. (2011). Motor Learning \& Performance, Illonois: Human Kinetics Books.

Robert Morgan, Developing Teaching Style, http://www.creativeteachingsite. com/teach3.html. Journal, Accessed 10 November 2016.

Robert N. Singer. (2006). Peak Performance and More. New York: Movement Publications.

Safrudin. (2008). Sports Tests and Measurement. Solo: UNS Press, Print II.

Sajoto, M. (2008). Improvement and Development of Strength and Physical Condition in Sport. Semarang: Dahara Prize.

Schraff, Robert. (2009). Easy and Easy Tennis Playing. Jakarta: Pearls.

Sharkey, Brian J. (2003). Fitness and Health. Jakarta: PT. Rajagrafindo Persada.

Simpson Peter. (2008). Ping Pong Playing Technique. Bandung: Pionir Jaya Publisher.

Slameto. (2013). Learning And Factors That Influence It. Jakarta: PT. Rineka.

Sofyan H. Achmad. (2011). Model Learning Table Tennis Game, Publisher PT. Bumi Timur Jaya, Jakarta, First Printing.

Sudjana. (2006). Design and Experimental Analysis, 8th Edition. Bandung: PT. Tarsito.

Suherman Adang. (2001). Assessment Learning in Physical Education. Jakarta: Ministry of National Education, Directorate General of Sports.

Sukadiyanto. (2011). Introduction to the Theory and Methodology of Physical Training. Bandung: CV. Lubuk Agung.

Sumosardjono, Sadoso. (2006). Physical condition. Bandung: Tarsito.

Supariasa, I Nyoman Dewa. (2001). Assessment of Nutrition Status. Jakarta: EGC Medicine Book.

Sutarmin. (2007). Skilled Exercising Table Tennis. Surakarta, Intermed Era.

Sutopo, Arie \& Alma Permana Lestari. (2001). Basic Physics Practical Guidebook. Jakarta: Jakarta State University.

Suyono et al. (2014). Learning and Learning. Bandung: PT Remaja Rosdakarya.

Syafruddin. (2010). The Basics of Sports Coaching. Padang: Faculty of Sports Science Padang State University.

Syaiful Bahri and Aswan Zain. (2005). Teaching and Learning Strategies. Jakarta: PT. Rineka Cipta.

Syaiful Sagala. (2012). Concepts and Meanings of Learning. Bandung: Alfabeta.

S. Nasution. (2010). Dikdaktik Teaching Principles. Jakarta: Earth Script.

Main A. Bandi. (2004). Learning Table Tennis Game. Yogyakarta, UNY Press.

Widiastuti. (2015). Tests and Measurements of Sports. Jakarta: Rajawali Pres.

William H. Edwards. (2010). Motor leaming and Control, Theory to Practice. New York .

William C. Thomson. (2013). VAHPERD Journal, Virginia Association for Health, Physical Education and Dance, COPYRIGHT 2009 Virginia Association for Health, Physical Education and Dance ISSN: 0739-4586 Date: Fall, 2009 Source Volume: 30 Source Issue: 2 www. Shark product.com/fitness, Tips For Heart Training, Monday, September 19. 